\title{
Splenic cysts: a report of six cases and a brief review
}

\author{
SAMI SHOUSHA* \\ M.D., M.R.C.Path. \\ Department of Histopathology, Royal Free Hospital, London, NW3
}

\begin{abstract}
Summary
Six cases of splenic cysts, removed surgically in the Royal Free Hospital during the last 10 years, are presented. These include a hydatid cyst, two primary, epithelium lined, and three secondary, non-epithelium lined cysts.

The histology, aetiology, symptomatology, diagnosis, treatment and complications of splenic cysts are discussed.

\section{Introduction}

Splenic systs are uncommon. During the last 10 years only six cases have been diagnosed and removed surgically in the Royal Free Hospital. These cases are now reported with a special emphasis on a recently encountered rare case with a transitional muco-epidermoid lining.
\end{abstract}

\section{Cases}

The important findings in the six cases are summarized in Table 1. Case no. 6 will be discussed in detail.

\section{Case 6}

A 14-year-old girl presented with a 2-year history of intermittent sharp pains in the left hypochondrium.

Examination showed a grossly enlarged spleen. Blood investigations were basically normal. Her ESR was $9 \mathrm{~mm}$ in one hour; total serum proteins $8.1 \mathrm{~g} / 100 \mathrm{ml}$; total albumin $4.5 \mathrm{~g}$; total globulin $1.4 \mathrm{~g}$; IgG $1530 \mathrm{mg} / 100 \mathrm{ml}$; IgA 180; IgM $249 \mathrm{mg} /$ $\mathrm{ml}$. Liver function tests, a liver biopsy and sternal marrow smear were all normal. Examination for sheep cell agglutination and anti-nuclear antibodies were negative. No oesophageal varices were seen by barium swallow and IVP was normal. Urine analysis showed proteinuria. This seemed to be postural since the early morning specimen of urine was normal.

A lymphangiogram showed normal lymphatic vessels and lymph nodes but the left kidney was depressed by the enlarged spleen. A free-flush aortogram and selective coeliac axis arteriogram were done. The aorta and its branches were displaced

\footnotetext{
* Present address: Department of Histopathology, Charing Cross Hospital, London, W.6.
}

to the right by the enlarged spleen. The liver vasculature appeared normal. The portal vein was patent. The spleen was compressed and displaced by a large rounded lucent and relatively avascular lesion which caused stretching of the splenic artery branches, indentation of the liver and depression of the left kidney. A diagnosis of splenic cyst of undetermined aetiology was made. The diagnosis was confirmed by a liver and splenic scan and ultrasonic examination. A Casoni test was negative.

At operation, a large spleen containing a bilocular cyst was excised. The cyst contained $2300 \mathrm{ml}$ of clear serous fluid. Cytological examination of the fluid showed no pus or red cells but some squamous cells. Cultures for bacteria were negative after $48 \mathrm{hr}$.

The spleen measured $17.0 \times 9.0 \times 6.0 \mathrm{~cm}$ and weighed $480 \mathrm{~g}$ without the fluid. The cyst measured $12.0 \times 9.0 \times 6.0 \mathrm{~cm}$ and had a trabeculated greyishbrown inner surface showing a few scattered small yellow patches (Fig. 1).

Microscopically the cyst wall consisted of fibrous tissue lined, in parts, by epithelium. The latter was mostly composed of stratified squamous cells, but areas of transitional epithelium were also present. Two types of stratified squamous epithelium were seen. One was thick, rich in glycogen, as seen by periodic acid Schiff (PAS) and Best's carmine stains and had an irregular lower surface resting on a thick layer of fibrous tissue. The other type was thinner, almost devoid of glycogen, had a straighter lower surface and included mucin-containing cells which stained positively with PAS and Alcian blue stains. These mucin-secreting cells were mostly arranged in groups either as intra-epithelial glandular structures, or an interrupted surface layer (Fig. 2). The transitional areas consisted of two to four layers of epithelium, the most superficial of which was cuboidal. It rested on a highly vascular, cavernous-like fibrous tissue.

The fibrous tissue wall of the cyst showed foci of calcification and of recent and old haemorrhages. Lipid deposits and a foreign body giant cell reaction were seen in areas of the wall uncovered by epithelium.

The splenic tissue, apart from the cyst, appeared congested but otherwise normal. 
TABLE 1. Summary of the important findings in the six splenic cysts

\begin{tabular}{|c|c|c|c|c|c|c|c|c|c|c|}
\hline \multirow[b]{2}{*}{$\begin{array}{l}\text { Case } \\
\text { no. }\end{array}$} & \multirow{2}{*}{$\begin{array}{l}\text { Sex } \\
\text { (age } \\
\text { in } \\
\text { years) }\end{array}$} & \multirow[b]{2}{*}{$\begin{array}{l}\text { Presenting } \\
\text { symptoms }\end{array}$} & \multicolumn{3}{|c|}{ Spleen } & \multicolumn{4}{|c|}{ Cyst } & \multirow[b]{2}{*}{ Remarks } \\
\hline & & & $\begin{array}{c}\text { Weight } \\
\text { (g) }\end{array}$ & $\begin{array}{l}\text { Size } \\
(\mathrm{cm})\end{array}$ & Histology & $\begin{array}{l}\text { Size } \\
(\mathrm{cm})\end{array}$ & $\begin{array}{c}\text { Fluid } \\
\text { content }\end{array}$ & Lining & Histology & \\
\hline 1. & $F(25)$ & $\begin{array}{l}\text { Abdominal } \\
\text { pain }\end{array}$ & 1500 & $\begin{array}{l}23 \times 11 \\
\times 11\end{array}$ & $\begin{array}{l}\text { Areas of } \\
\text { haemorrhage }\end{array}$ & $\begin{array}{l}2 \text { cysts } \\
\text { each } 12 \\
\times 11 \times \\
10\end{array}$ & Clear & $\begin{array}{l}\text { White } \\
\text { membrane }\end{array}$ & $\begin{array}{l}\text { Hydatid } \\
\text { cyst }\end{array}$ & $\begin{array}{l}\text { Hydatid cysts } \\
\text { also present } \\
\text { in liver, kidney } \\
\text { and peritoneum. } \\
\text { Patient is a } \\
\text { Greek Cypriot }\end{array}$ \\
\hline 2. & $F(8)$ & $\begin{array}{l}\text { Abdominal } \\
\text { pain }\end{array}$ & $\mathbf{N A}^{*}$ & NA & Normal & NA & $\begin{array}{l}400 \mathrm{ml} \\
\text { opaque, } \\
\text { dark } \\
\text { brown }\end{array}$ & $\begin{array}{l}\text { Trabecu- } \\
\text { lated }\end{array}$ & $\begin{array}{l}\text { Epidermoid } \\
\text { cyst }\end{array}$ & $\begin{array}{l}\text { Reported by } \\
\text { Talerman and } \\
\text { Hart (1970) }\end{array}$ \\
\hline 3. & $F(42)$ & $\begin{array}{l}\text { Attacks of } \\
\text { diaphragmatic } \\
\text { spasms and } \\
\text { subcostal } \\
\text { discomfort }\end{array}$ & 165 & $\begin{array}{c}11 \times 9 \\
\times 5\end{array}$ & Congested & $4 \cdot 5$ & None & $\begin{array}{l}\text { Calcified, } \\
\text { pale } \\
\text { yellow }\end{array}$ & $\begin{array}{l}\text { Calcified } \\
\text { fibrous tissue } \\
\text { wall }\end{array}$ & \\
\hline 4. & $\mathbf{M}(39)$ & $\begin{array}{l}\text { Discomfort } \\
\text { in left loin } \\
\text { associated } \\
\text { with large } \\
\text { swelling after } \\
\text { fall at age of } \\
\text { 15. The } \\
\text { swelling has } \\
\text { progressively } \\
\text { enlarged since } \\
\text { then }\end{array}$ & 500 & NA & Congested & $15 \cdot 0$ & NA & NA & $\begin{array}{l}\text { Calcified } \\
\text { fibrous } \\
\text { tissue wall }\end{array}$ & 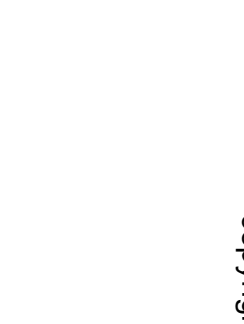 \\
\hline 5. & $\mathbf{M}(76)$ & $\begin{array}{l}\text { None related } \\
\text { to spleen }\end{array}$ & 225 & NA & Normal & $4 \cdot 0$ & NA & NA & $\begin{array}{l}\text { Calcified } \\
\text { fibrous } \\
\text { tissue wall }\end{array}$ & $\begin{array}{l}\text { Discovered } \\
\text { accidentally during } \\
\text { operation for } \\
\text { carcinoma of colon }\end{array}$ \\
\hline 6. & $F(14)$ & $\begin{array}{l}\text { Intermittent } \\
\text { sharp pain in } \\
\text { left groin }\end{array}$ & 480 & $\begin{array}{l}17 \times 9 \\
\times 6\end{array}$ & Congested & $\begin{array}{l}12 \times 9 \\
\times 6\end{array}$ & $\begin{array}{l}\text { Clear } \\
\text { serous } \\
\text { fluid }\end{array}$ & $\begin{array}{l}\text { Trabecu- } \\
\text { lated }\end{array}$ & $\begin{array}{l}\text { Transitional } \\
\text { muco- } \\
\text { epidermal } \\
\text { cyst }\end{array}$ & $\begin{array}{l}\text { The case reported } \\
\text { in detail in this } \\
\text { article }\end{array}$ \\
\hline
\end{tabular}

* NA - Data not available.

\section{Histology of cases 3, 4 and 5 (secondary cysts)}

All three cysts were lined with fibrous tissue showing wide areas of calcification. No epithelial lining was seen in several sections taken from various sites. The appearance was similar to that seen in the areas denuded of epithelium in Case 6.

\section{Discussion}

Splenic cysts may be parasitic, hydatid cysts, or non-parasitic. The latter are classified into primary and secondary cysts according to the presence or absence, respectively, of an epithelial lining (Qureshi and Hafner, 1965).

Most of the primary, non-parasitic, cysts are lined with stratified squamous epithelium, hence they are also known as epidermoid cysts. However, the lining may be flattened or completely lost in some areas
(Qureshi and Hafner, 1965). Fifty-six cases of epidermoid cysts have been reported in the literature (Garfunkle, 1976). Primary cysts lined with flat (Qureshi and Hafner, 1965) and transitional epithelium (Fonkalsrud and Walford, 1960) were also reported.

The aetiology of primary cysts is debatable. Although trauma sometimes plays a role in bringing them to attention, it is an extremely doubtful primary cause (Tsakraklides and Hadley, 1973). The theory accepted by most authors is that they develop from 2 embryonic cellular inclusions in the developing spleen (Linn and Ellias, 1949). Five possible types of cellular inclusions have been proposed, namely totipotent (Browne, 1963), ectodermal (Mahour, Soule and Lynn, 1968), mesothelial (Linn and Ellias, 1949), endodermal (Lipit, Akhavan and Caplan, 


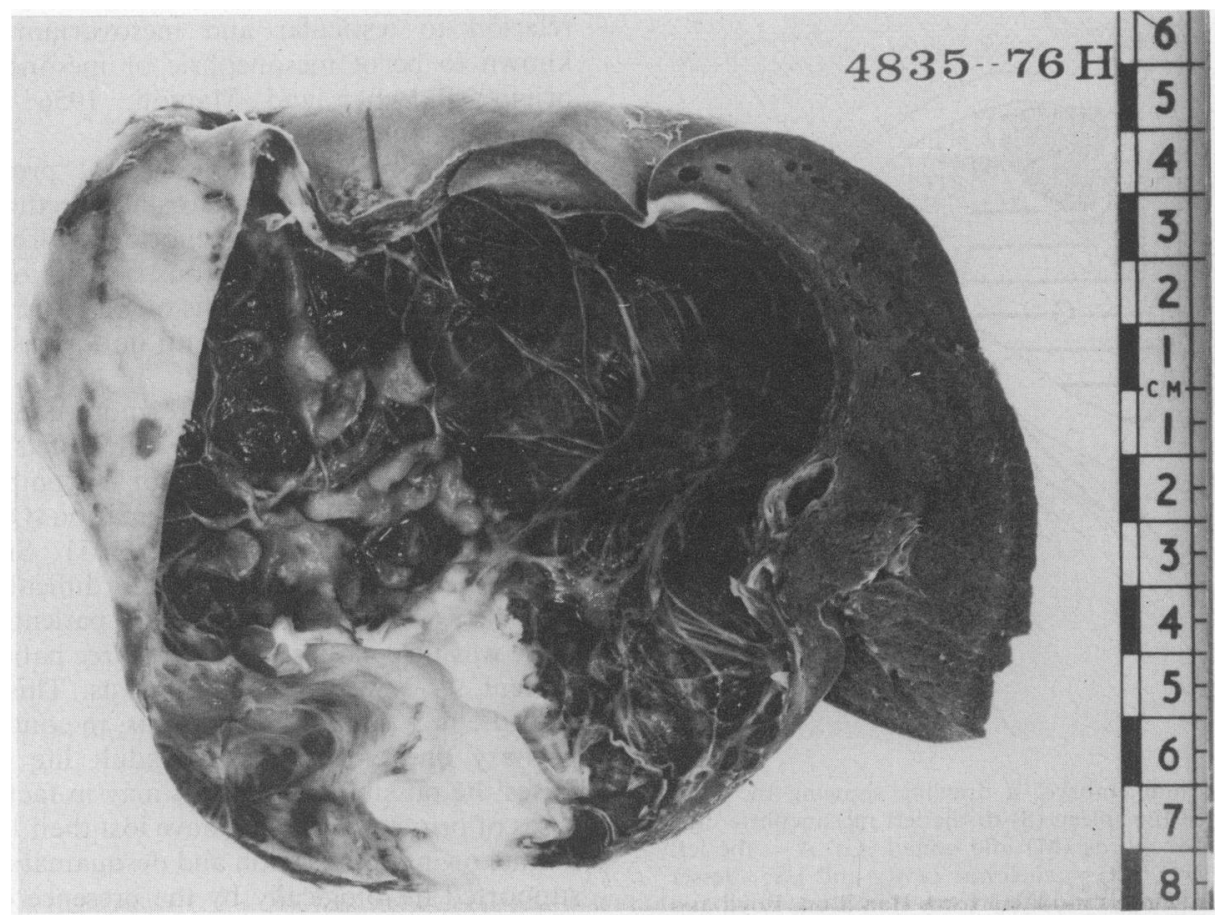

FIG. 1. Primary (epidermoid) splenic cyst, Case 6. Note the trabeculated lining.

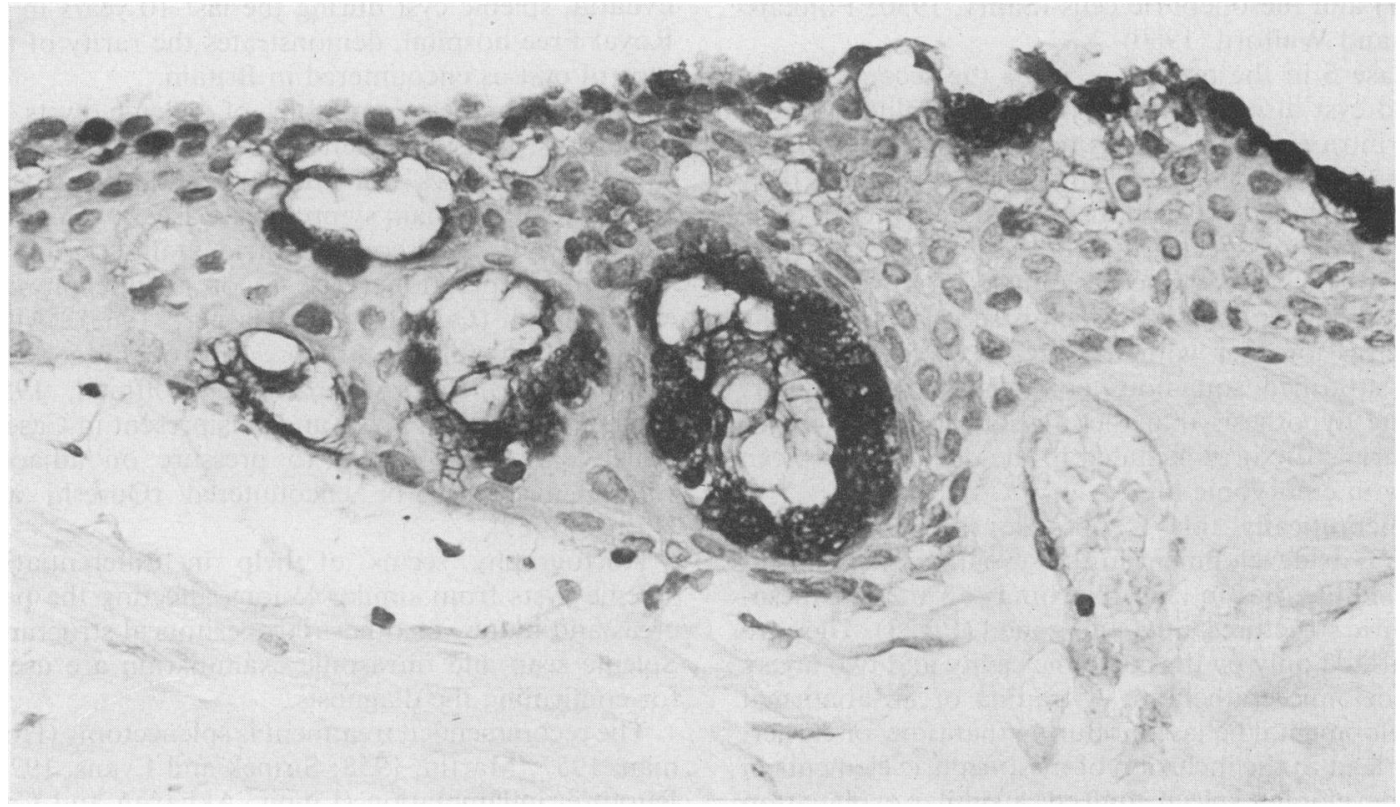

FIG. 2. Case 6. Part of the wall lined with non-keratinized stratified squamous epithelium containing intra-epithelial mucous glands and an interrupted surface layer of mucus-containing cells. The squamous cells are devoid of glycogen. (PAS, $\times 85$.) 


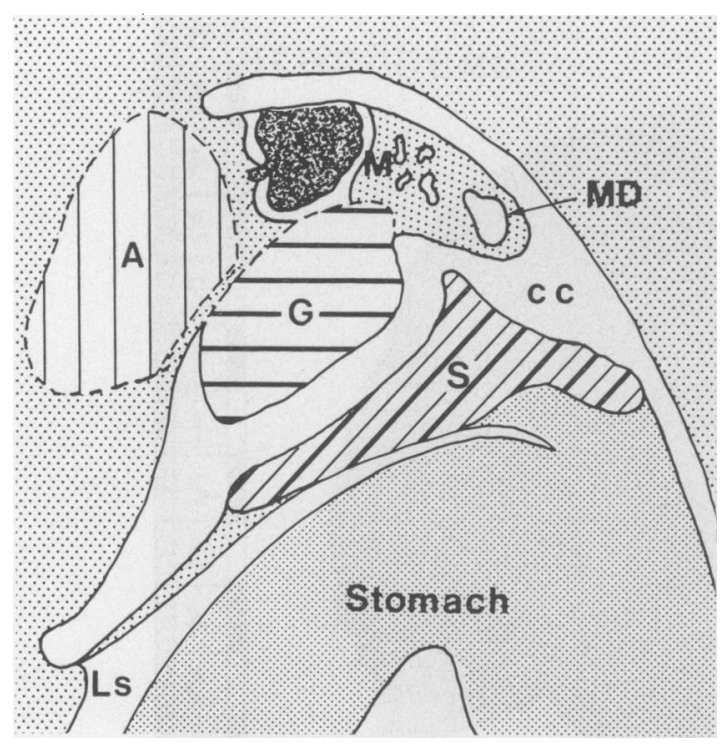

FIG. 3. $14 \mathrm{~mm}$ embryo, a drawing showing the close proximity of the spleen (S) to the left mesonephric duct (MD), mesonephros (M) and gonad (G). $A=$ the left adrenal gland, $\mathrm{CC}=$ coelomic cavity and $\mathrm{LS}=$ lesser sac. The drawing is modified from Hamilton, Boyd and Mossman (1959).

1967) and mesonephric cells (Santy, 1930; Fonkalsrud and Walford, 1960).

Case 6 in the present series is the second epidermoid cyst also containing islands of columnar cells and intra-epithelial glands to be reported. Linn and Ellias (1949) reported a similar appearance in their case but failed to demonstrate mucin in the cells. They did not specify the stains they used, nor the state of the tissues when examined. The presence of this type of epithelium, which is seen in parts of the urethra, together with the presence of transitional and stratified squamous epithelium lends support to the hypothesis that these cysts arise from mesonephric structures included in the developing spleen early in embryonic life.

Theoretically this is possible since the spleen, during its development in the seventh week of intrauterine life, lies in close proximity to the left mesonephric structures, duct and gonad (Fig. 3). They are separated only by the coelomic cavity and two layers of coelomic epithelium. A trauma or an abnormal developmental behaviour during that time, or earlier, may lead to the inclusion of mesonephric elements in the developing spleen. Indeed, a similar explanation was put forward by Almenoff (1966) and Watson (1968) to explain the occasional presence of aberrant splenic tissue in close contact with the gonads, in relation to testicular and mesovarium structures known to be of mesonephric or mesonephric duct origin (Putschar and Manion, 1956; Almenoff, 1966; Watson, 1968).

On this developmental basis, the presence of a congenital stricture of the prostatic urethra in a case of splenic epidermoid cyst reported by Browne (1963) may be more than a fortuitous association and congenital genito-urinary lesions ought to be looked for more carefully in patients with non-parasitic splenic cysts.

Secondary splenic cysts are more common than primary cysts. They are usually attributed to trauma, haemorrhage, inflammation or thrombosis with subsequent necrosis and cyst formation (Qureshi and Hafner, 1965; Park and Song, 1971; Sirinek and Evans, 1973). However, it is usually difficult to obtain a history supporting this from patients. Indeed, there was no such history in the three patients of the present series with secondary cysts. This, together with the fact that secondary cysts, in contrast to the primary ones, occur late in adult life (Table 1), raises the possibility that they may in fact represent cases of primary cysts that have lost their lining after a time, owing to irritation and desquamation. This is supported histologically by the presence of patches denuded of epithelium in the walls of proved primary cysts which appear microscopically exactly simila to the walls of secondary cysts.

The diagnosis of only one case of parasitic, hydatid, splenic cyst during the last 10 years in the Royal Free hospital, demonstrates the rarity of this type of cyst as encountered in Britain.

The commonest symptom of splenic cysts, in general, is pain in the left loin. This was present in five of the six cases. Sometimes an abdominal swelling is one of the main symptoms (Case 4). Occasionally the cyst is discovered incidentally during an abdominal operation (Case 5) or routine physical examination (Qureshi and Hafner, 1965). Albuminuria, probably due to pressure on kidney, has been reported in several cases (Hoffman, 1957; Allen and Condon, 1961) and was present in Case 6. Other symptoms related to pressure on adjacent viscera may also be encountered (Qureshi and Hafner, 1965).

Aortography seems of help in differentiating splenic cysts from similar lesions affecting the pancreas and kidney or other retroperitoneal structures. Splenic scan and ultrasonic examination are useful for confirming the diagnosis.

The recommended treatment is splenectomy (Hoffman, 1957; Martin, 1958; Sirinek and Evans, 1973). Rupture, inflammation (Lippit, Akhavan and Caplan, 1967), and acute abdomen (Dibble and Weigen, 1965) have been reported as complications of untreated splenic cysts. 


\section{Acknowledgments}

I would like to thank Professor K. E. F. Hobbs for his permission to publish Case 6 in detail, Professor G. B. D. Scott, Professor P. J. Scheuer and Professor B. Harris of the Royal Free Hospital School of Medicine for their valuable advice and discussion, Miss Barbara Archer for the technical work, Mr Paul Bates for the photography and the drawing, and Mrs Margaret Withnall for the typing.

\section{References}

Allen, R.B. \& Condon, U.R. (1961) Epidermoid cysts of the spleen in children. American Journal of Roentgenology, Radium Therapy and Nuclear Medicine, 86, 534.

Almenoff, I.A. (1966) Splenic-gonadal fusion. New York State Journal of Medicine, 66, 1679.

Browne, M.K. (1963) Epidermoid cyst of the spleen. British Journal of Surgery, 50, 838.

Dibble, J.B. \& Weigen, C.E. (1965) Epidermoid cyst of the spleen presenting as an abdominal emergency. Report of a case. Journal of American Medical Association, 194, 1144.

FonKALSRUD, E.W. \& WALFORD, R.L. (1960) Transitional cell splenic cyst excised without splenectomy. Archives of Surgery, 81, 636.

GARFUNKLE, F. (1976) Epidermoid cyst of the spleen: Case report. Journal of Nuclear Medicine, 17, 196.

Hamilton, W.J., Boyd, J.D. \& Mossman, H.W. (1959) Human Embryology, 2nd Edn, p. 207. W. Heffer \& Sons Ltd, Cambridge.
Hoffman, E. (1957) Non-parasitic splenic cysts. American Journal of Surgery, 93, 765.

LinN, H.J. \& Ellias, E.P. (1949) Epidermoid cyst of the spleen. Report of a case. American Journal of Clinical Pathology, 19, 558.

Lippitt, W.H., Akhavan, T. \& Caplan, G.E. (1967) Epidermoid cyst of the spleen with rupture and inflammation. Archives of Surgery, 95, 74.

Mahour, G.H., Soule, E.H. \& LynN, H.B. (1968) Multiple epidermoid cysts of the spleen. Archives of Surgery, 96, 394.

Martin, J.W. (1958) Congenital splenic cysts. American Journal of Surgery, 96, 302.

PARK, J.Y. \& Song, K.T. (1971) Splenic cysts: A case report and review of literature. American Surgeon, 37, 544.

Putschar, W.G.J. \& Manion, W.C. (1956) Splenic-gonodal fusion. American Journal of Pathology, 32, 15.

QuReshi, M.A. \& HAFNeR, C.D. (1965) Clinical manifestations of splenic cysts. Study of 75 cases. American Surgeon, 31, 605.

SANTy, P. (1930) Splénectomie pour un kyste vrai de la rate chez un enfant. Lyon chirurgical, 27, 101.

SIRINEK, K.R. \& Evans, W.E. (1973) Non parasitic splenic cysts. Case report of epidermoid cyst with review of the literature. American Journal of Surgery, 126, 8.

Talerman, A. \& Hart, S. (1970) Epithelial cysts of the spleen. British Journal of Surgery, 57, 201.

Tsakraklides, V. \& Hadley, T.W. (1973) Epidermoid cysts of the spleen. A report of five cases. Archives of Pathology, 96, 251.

WATSON, R.J. (1968) Splenogonadal fusion. Surgery, 63, 853. 